Revista lus et Praxis, Año 25, № 3, 2019, pp. 215 - 248

ISSN 0717 - 2877

Universidad de Talca - Facultad de Ciencias Jurídicas y Sociales

El consentimiento informado de las personas menores

de edad en el ámbito de la salud

Darío Parra Sepúlveda - Isaac Ravetllat Ballesté

Trabajo recibido el 8 de enero y aprobado el 10 de agosto de 2019

\title{
El consentimiento informado de las personas menores de edad en el ámbito de la salud*
}

\author{
INFORMED CONSENT TO THE MEDICAL TREATMENT OF MINORS
}

\author{
Darío Parra Sepúlveda* \\ ISAAC RAVETLLAT BALLESTE $E^{* * *}$
}

\begin{abstract}
Resumen
El binomio protección versus autonomía se presenta como un dato clave en la reciente evolución del tratamiento jurídico de los derechos de la niñez y la adolescencia, siguiendo la pauta marcada por la Convención sobre los Derechos del Niño y presidido por los principios del interés superior del niño y la capacidad progresiva del individuo. El presente artículo se interesa por ahondar cuál es el régimen jurídico de la capacidad para ejercitar los derechos de la personalidad, en particular el derecho a la vida y a la integridad física, en el caso de que su titular sea una persona menor de edad. En otras palabras, cuál es el poder de disposición que ostentan niños, niñas y adolescentes sobre su vida e integridad corporal en el ámbito de la actividad facultativa y terapéutica.
\end{abstract}

\section{ABSTRACT}

The protection versus autonomy binomial is presented as a key factor in the recent evolution of the legal treatment of the rights of children and adolescents, following the pattern of the Convention on the Rights of the Child and presided over by the principles of the best interests of the Child and the individual's progressive ability. The present article is interested in deepening the legal status of capacity to exercise the rights of the personality, in particular the right to life and physical integrity, in case the holder is a minor. In other words, what is the power of disposition that children and adolescents have about their life and physical integrity in the field of medical and therapeutic activity.

PALABRAS CLAVE

Infancia y adolescencia, capacidad progresiva, consentimiento informado.

\footnotetext{
* Este trabajo se enmarca en el Proyecto de Investigación Fondecyt N N 11160566, titulado "Los deberes del facultativo en la responsabilidad civil médica: Análisis crítico, propuesta de sistematización y contenido", del cual el autor Dr. Darío Parra es investigador responsable.

** Profesor de Derecho Civil de la Facultad de Ciencias Jurídicas y Sociales de la Universidad Austral de Chile. Abogado, doctor en Derecho por la Universidad Carlos III de Madrid, España. Correo electrónico: dario.parra@uach.cl

*** Profesor asociado de Derecho Civil de la Facultad de Ciencias Jurídicas y Sociales de la Universidad de Talca, Chile. Doctor en Derecho por la Universidad de Barcelona, España. Director del Centro de Estudios sobre los Derechos de la Infancia y la Adolescencia de la Universidad de Talca. Secretario general de la Asociación para la Defensa de los Derechos de la Infancia y la Adolescencia (ADDIA). Vocal del Observatorio de Infancia del Gobierno de la Generalitat de Cataluña, España. Correo electrónico: iravetllat@utalca.cl
} 
KEYWORDS

Childhood and adolescence, progressive capacity, informed consent.

\section{Introducción}

Uno de los aspectos en los que más ha hecho evolucionar la relación médicopaciente ha sido en el relativo al papel de la voluntad de este último' ${ }^{1}$. Si bien desde sus inicios y hasta no hace muchas décadas, a raíz de la marcada concepción paternalista que regía este tipo de vínculos, era el facultativo quien tenía la potestad absoluta de adoptar las decisiones que estimara oportunas en materia médica, siendo el paciente un mero sujeto pasivo de la asistencia sanitaria ${ }^{2}$, en la actualidad, en cambio, se ha consolidado la salvaguarda de la autonomía de la voluntad del paciente, fundamentalmente a partir de la toma de conciencia de que la decisión de someterse o no a un determinado acto médico supone en última instancia un acto de ejercicio del derecho a la autodeterminación como manifestación de la libertad del individuo. Así, se ha consolidado la evolución de la concepción del paciente, pasando de ser un sujeto pasivo de la relación médica a ser considerado como titular de derechos ${ }^{3}$.

En efecto, uno de los sectores en que más ilustrativo y lleno de matices se ha mostrado el limitado poder de disposición que el individuo, y ni qué decir del niño, niña o adolescente, ostenta sobre su vida e integridad corporal es la actividad facultativa y terapéutica ${ }^{4}$. En este contexto, tradicionalmente, se consideró a las personas que todavía no habían alcanzado la mayoría de edad como sujetos absolutamente incapaces de poder participar, ya sea directa o indirectamente, en la toma de decisiones vinculadas con su estado de salud, más aún tratándose de su salud sexual y reproductiva. De esta forma, el paciente menor de edad era considerado como un mero objeto pasivo de intervención y, en consecuencia, debía actuar y consentir por él su representante legal ${ }^{5}$. Ahora

1 García (2010), p. 97.

2 Parra (2014), pp. 208-210.

3 Barros (2016), p. 682. En este contexto, Asensio (2012), p. 56, defiende que el consentimiento informado es fruto de una nueva visión de la enfermedad entendida ya no como un desorden atinente al plano moral, que situaba al enfermo en una posición poco menos que de minusvalía o de inferioridad respecto al médico y lo incapacitaba para tomar decisiones sobre su salud, sino de un desorden eminentemente de carácter físico y biológico que, de ordinario, no incapacita al enfermo para tomar decisiones sobre la salud y que, consecuentemente, conlleva una nueva visión o concepción de las relaciones médico-paciente $y$, por ende, de la medicina y el derecho.

${ }^{4}$ Lama (2006), pp. 319-321, y Gete-Alonso (1998), pp. 48-53.

5 García (2000), p. 98; Ruiz (2009), pp. 81-82; García (2012), p. 99; González (2005), pp. 1618-1620,

y Craven-Bartle (2005), pp. 129-153. 
bien, el tratamiento normativo irrogado a estas situaciones empezó a experimentar un cambio sustancial de tendencia a partir de finales del pasado siglo. El punto de inflexión de esta metamorfosis vino provocado por el advenimiento de una nueva filosofía acerca de la verdadera naturaleza de la declaración de voluntad en el ámbito sanitario. El denominado consentimiento informado pasó a ser concebido como un acto de ejercicio de los derechos fundamentales y de la personalidad del individuo, no susceptibles, por definición, de representación legal ${ }^{6}$.

Nuestro ordenamiento jurídico no ha estado ajeno a esta evolución y, en concordancia con la tendencia apuntada, en el mes de abril del año 2012 se promulgó la Ley $N^{\circ} 20.584$, que viene a reconocer al paciente como un sujeto activo de la relación médica, capacitándolo para adoptar decisiones de forma autónoma en el ámbito sanitario. Cabe agregar que la citada normativa, tanto en su mensaje como en su párrafo $6^{\circ}$, hace alusión expresa al respeto de la autonomía del paciente como principio rector que debe regir la relación entre éste y el médico ${ }^{7}$.

Realizada dicha prevención, intentaremos presentar algunas ideas relevantes en torno al consentimiento informado en el ámbito sanitario como competencia exclusiva del paciente y en especial trataremos de dar solución a la interrogante acerca de si le corresponde a la persona menor de edad (niño, niña o adolescente) el ejercicio directo de esta prerrogativa, considerando que durante la tramitación de la mentada Ley № 20.584 se eliminó, en este ámbito, toda referencia expresa a las personas menores de edad, que el proyecto, en cambio, sí incorporaba.

Para ello, analizaremos en primer término el alcance y significación jurídica de la declaración de voluntad emitida por el paciente legitimando la actuación del facultativo y excluyendo, por ende, la antijuricidad del acto, el conocido como consentimiento informado. Efectuadas estas reflexiones de corte más general, proseguiremos, acto seguido, con el estudio detallado de la concreción legal adoptada por los derechos de la personalidad, en concreto el derecho a la vida y a la integridad corporal, cuando su titularidad y ejercicio corresponden a un individuo que todavía no ha alcanzado la mayoría de edad. Finalmente, concluiremos haciendo especial énfasis a la delimitación de cuál es el cuerpo normativo que reconoce a los adolescentes el derecho a la toma de decisiones en el ámbito sanitario, tratando de poner de manifiesto las contradicciones y lagunas existentes al respecto en nuestro ordenamiento jurídico.

${ }^{6}$ Ravetllat (2013), pp. 29-37, y Ravetllat y Sanabria (2016), pp. 60-61.

7 PARRA (2018), p. 332. 


\section{Algunas notas generales acerca del consentimiento informado}

Definir de manera íntegra el significado del consentimiento informado no resulta nada fácil, dada la variedad de perfiles que el mismo evoca en razón de la notable evolución que la relación médico-paciente ha experimentado en las últimas décadas. Es por ello que, a efectos de la sistemática de nuestro estudio, nos interesa resaltar la idea de que la integridad personal de cualquier paciente sólo podrá verse invadida por el personal sanitario en la medida en que aquél, previa comprensión de las implicancias de la intervención, consienta una determinada actuación médica. De este modo, aparece, como principal justificación de la exigencia del consentimiento informado, la tutela de la autodeterminación de los pacientes ${ }^{8}$.

No obstante, y antes de adentrarnos en la compleja madeja que implica determinar los contornos del consentimiento informado, resulta interesante destacar brevemente una de las cuestiones que ya se ha ocupado de aclarar la doctrina ${ }^{9}$, que no es otra que la diferencia existente entre el consentimiento que presta el paciente autorizando una intromisión en su propio cuerpo y el denominado consentimiento contractual, que por ejemplo prestaría tanto el paciente como el médico al celebrar el contrato de asistencia sanitaria. Efectivamente, el consentimiento informado, o como lo denominan algunos autores el consentimiento-legitimación ${ }^{10}$, se establece como un derecho inalienable en que por exigencia legal el paciente dispone de su propio cuerpo garantizando la licitud de una actividad médica determinada. Por su parte, el consentimiento contractual, por esencia voluntario, es el punto de encuentro de aquellas voluntades que pretenden quedar obligadas por un acto jurídico, encontrando su regulación en las normas que cada ordenamiento dedica a la formación del contrato ${ }^{11}$.

Una vez realizadas las prevenciones del caso, cabe centrarnos en la normativa que regula el consentimiento informado como deber exigible al facultativo en el desempeño de su actividad profesional. Al respecto, se debe subrayar que, de una primera lectura del articulado de la Ley $^{\circ} 20.584$, puede extraerse que el consentimiento informado se constituye en uno de los pilares sobre el que se erige y sustenta todo el sistema. Así, el artículo 14 del citado cuerpo legal, ubicado en el párrafo $6^{\circ}$, titulado "De la autonomía de las personas en su atención de salud", pone de relieve la exigencia del voluntario y previo -a la

8 Barros (2016), pp. 682-683.

9 Gitrama (1977), p. 283, y Ataz (1985), pp. 54 y ss.

10 Llamas (1988), p. 156, y Domínguez (2008), p. 298.

11 Alessandri (2005), p. 6. 
realización de cualquier actuación médica-consentimiento de los pacientes, el cual necesariamente deberá obtenerse después de haber recibido la respectiva información en forma oportuna y comprensible. Por su parte, el Decreto № 31 del Ministerio de Salud, complementando las disposiciones de la Ley № 20.584, establece un reglamento que versa específicamente sobre la entrega de información y expresión del consentimiento informado en las atenciones de salud.

Asimismo, también puede destacarse lo dispuesto en el artículo 16 de la referenciada norma, precepto éste que expresa que "la persona que fuere informada de que su estado de salud es terminal, tiene derecho a otorgar o denegar su voluntad para someterse a cualquier tratamiento que tenga como efecto prolongar artificialmente su vida". Una última referencia a este deber la encontramos en el inciso $3^{\circ}$ del artículo 14 de la propia ley, en que se contiene la obligación de dejar constancia escrita del correspondiente consentimiento informado del paciente en su ficha clínica ${ }^{12}$.

Avanzando en los contornos de la institución objeto de nuestro análisis, no cabe duda de la estrecha correlación que existe entre información y consentimiento ${ }^{13}$, prueba de ello es la propia terminología empleada -consentimiento informado- ${ }^{14}$ para referirse específicamente a la aquiescencia que da el paciente al facultativo para que este último realice determinadas actividades médicas en su cuerpo. Consecuencia de lo anterior, es la consagración de la doctrina conforme a la cual el facultativo no podrá amparar su actuar en el correcto ejercicio de la lex artis si infringe los deberes de informar al paciente y de obtención de su consentimiento informado ${ }^{15}$.

Superada así la clásica concepción paternalista de la relación médicopaciente y sumada a la toma de conciencia que el consentimiento de este último entraña el ejercicio de sus derechos de la personalidad, el consentimiento informado no sólo se ha erigido en pieza básica del futuro trato entre galeno y paciente, sino que también se ha trasformado en uno de los elementos básicos

\footnotetext{
12 A modo de crítica, si bien la citada normativa hace alusión al consentimiento informado, dedicándole incluso un título dentro del párrafo $6^{\circ}$, no entrega un concepto de qué ha de entenderse por consentimiento informado, como sí ocurre en otras legislaciones, como por ejemplo en la española, en donde en el artículo $3^{\circ}$ de la Ley $N^{\circ} 41 / 2002$ lo define como "la conformidad libre, voluntaria y consciente de un paciente, manifestada en el pleno uso de sus facultades después de recibir la información adecuada, para que tenga lugar una actuación que afecta a su salud".

13 Un estudio histórico comparado lo encontramos en Martínez-Pereda (2006), pp. 1 y ss.

${ }^{14}$ Destacando que terminológicamente no es la denominación más adecuada, la doctrina especializada ha propuesto otras denominaciones, como consentimiento del paciente previamente informado, asentimiento del paciente, autorización al tratamiento o consentimiento sanitario. Sobre el particular se manifiesta FERNÁNDEZ (2007), p. 277.

15 Galán (2016), pp. 621 y ss.
} 
a la hora de determinar la existencia y extensión de la responsabilidad civil en el ámbito médico-sanitario ${ }^{16}$, configurándose en la actualidad como un elemento fundamental de los denominados deberes propios de la profesión sanitaria, cuya infracción, no hay duda, implicará que el actuar del agente dañoso sea calificado de negligente y más aún, en algunos casos, dicha infracción podría incluso configurar una especie de perjuicio autónomo, como lo sería una especie de daño extrapatrimonial por infracción a la autodeterminación del paciente, como así lo ha entendido, por ejemplo, el supremo español ${ }^{17}$.

Cabe destacar, en este punto, que la mera infracción de alguno de los deberes que integran la denominada lex artis ad hoc no resulta suficiente para accionar el engranaje de la responsabilidad civil; en otras palabras, la verificación de la infracción de alguno de los deberes que conforman el estándar de conducta del médico sólo nos lleva a concluir la existencia de uno de los elementos de la responsabilidad civil, que es la culpa del agente, faltando en consecuencia la acreditación del daño y nexo causal entre tal infracción y el perjuicio sufrido por el paciente para que pueda prosperar una acción aquiliana en contra del facultativo.

En suma, desde una perspectiva jurídica, puede afirmarse que el consentimiento informado desempeña una doble función: en primer término, viene a legitimar la interferencia que el facultativo realiza en la integridad personal del paciente, $y$, en segundo lugar, traslada el riesgo de la intervención correctamente ejecutada desde el médico hacia el paciente ${ }^{18}$. Ello siempre y cuando exista

16 García (2010), p. 15.

17 Al respecto, interesante resulta destacar el pronunciamiento que el Tribunal Supremo español hace en su sentencia de 13 de mayo de 2011, en donde, a raíz de la reclamación que realiza la actora en contra del médico tratante y la compañía aseguradora por una negligencia en la realización de intervención quirúrgica no autorizada ni informada en su menisco izquierdo, el alto tribunal español entiende que la omisión del deber de información configura por sí sola un perjuicio autónomo -lesión a la autodeterminación- que debe ser indemnizado, al destacar que "... No es el daño que resulta de la intervención programada puesto que no se produjo, sino el daño que resulta de la que sí se llevó a cabo con la que no solo no logró mejorar sus dolencias en la rodilla, sino que se le privó de conocer los riesgos y beneficios posibles para su salud, puesto que ninguna información hubo respecto de una actuación médica que desconocía. La falta de información configura en este caso un daño moral grave, al margen de la corrección con que se llevó a cabo la intervención, puesto que ningún daño corporal se produjo, según los hechos probados de la sentencia. Un daño que fundamenta la responsabilidad por lesión del derecho de autonomía del paciente respecto de los bienes básicos de su persona, como presupuesto esencial para poder decidir libremente sobre la solución más conveniente a su salud, a su integridad física y psíquica y a su dignidad". Sentencia del Tribunal Supremo de 13 de mayo de 2011 (RJ 2011, 3279).

18 Para De LA MAZA (2010), p. 96, cabe precisar que la transferencia del riesgo estará condicionada al cabal cumplimiento del deber de información, lo cual implica que, en caso de que el médico incumpla con este deber, el riesgo de la intervención necesariamente deberá ser asignado a éste. 
un cabal cumplimiento del deber previo de entrega de información por parte del facultativo, lo cual implica que, en caso de que el médico incumpla con este deber, el riesgo de la intervención se mantendrá radicado en su persona.

Centrándonos ahora en la primera de las funciones que jurídicamente desempeña el consentimiento informado, cabe destacar particularmente el efecto legitimador que dicha aquiescencia otorga a la actuación del médico en el cuerpo del paciente, puesto que viene a convertir en lícitos ciertos comportamientos del facultativo que de otra manera serían jurídicamente reprochables ${ }^{19}$. Es en virtud de lo anterior que en no pocas oportunidades se ha resaltado el carácter de especificidad que debe tener este consentimiento, por lo que su otorgamiento necesariamente debe limitarse a una operación o actividad facultativa determinada, no resultando válido aquel consentimiento genérico que incluya todas las intervenciones y prácticas que, dependiendo del estado de salud del sujeto, puedan tornarse necesarias ${ }^{20}$.

Por último, teniendo en consideración lo expresado sobre el efecto legitimador que produce el consentimiento del paciente en la actividad médica, cabe realizar dos precisiones al respecto: una, relativa al hecho de que el consentimiento del paciente, aun cuando haya sido válidamente otorgado, no tiene una eficacia legitimadora absoluta, excluyéndose por ende aquellas prestaciones médicas ilícitas ${ }^{21}$, inmorales o contrarias a derecho; otra, referida a que este consentimiento informado tampoco liberará al facultativo de las consecuencias que pudiera acarrearle una conducta imprudente o negligente, eximiéndolo sólo de la responsabilidad en caso de concurrencia de uno de los riesgos previamente informados al paciente -puesto que, al ser debidamente informado y consentir en la actuación médica, es el paciente quien asume los riesgos, y no el médico-, siempre y cuando su materialización se produzca a pesar de la buena práctica del facultativo.

\section{El consentimiento informado y la minoría de edad en el ámbito sanitario}

Antes de proceder al estudio pormenorizado de la capacidad que ostentan las personas menores de edad para poder emitir por sí, de forma autónoma, una declaración de voluntad informada autorizando una determinada actuación o tratamiento médico -u oponiéndose al mismo-, consideramos imprescindible abordar tres aspectos de particular importancia. En primer término, el categorizar el derecho a la vida y a la integridad corporal como derechos de la

\footnotetext{
19 SÁnchez (2002), p. 65.

20 LÓPEZ (2007), p. 355.

21 SÁNCHEZ (2002), p. 295.
} 
personalidad nos lleva a cuestionarnos acerca del régimen jurídico aplicable a los actos de ejercicio de este tipo de derechos cuando su titularidad recae sobre personas menores de edad, enfatizando, de manera muy especial, las características propias de su particular naturaleza jurídica. A continuación, y a modo de ubicar el verdadero origen de la consideración de las personas menores de edad como capaces en el ámbito sanitario, focalizaremos nuestro interés en la denomina competencia Gillick, institución propia del common law que sirvió como estímulo, o detonante si se prefiere, del reconocimiento normativo de las competencias que el sector poblacional más joven ostenta sobre el mentado ámbito material. Y, por último, nos referiremos al derecho de los niños, niñas y adolescentes a recibir una información adecuada para poder tomar decisiones conscientes con respecto a su estado de salud.

\subsection{La capacidad natural como elemento esencial para el ejercicio de los derechos de la personalidad}

La tendencia seguida por el ordenamiento jurídico chileno de otorgar relevancia a la denominada capacidad natural o madurez como sustrato esencial sobre el que fundamentar la capacidad de ejercicio de los niños, niñas y adolescentes, es especialmente marcada en el ámbito de los derechos de la personalidad - $\mathrm{O}$, dicho de otro modo, en el ámbito de los actos jurídicos extrapatrimoniales ${ }^{22}$-, y es precisamente en este contexto en el que surgieron las primeras voces partidarias de sostener que, si bien la dicotomía capacidad de goce-capacidad de ejercicio podía tener todavía cierta relevancia en el ámbito patrimonial, era, en cambio, insostenible en el ámbito de la personalidad -extrapatrimonial ${ }^{23}$-.

\footnotetext{
22 Barcia (2013), pp. 3-52, y Ravetllat (2016a), pp. 213-224.

${ }^{23}$ En la doctrina chilena, EsPejO (2016), p. 204, sostiene que, en contra de las ideas tutelares sobre la infancia, el Derecho de la infancia contemporáneo se basa en la idea de los niños como sujetos legales, portadores de derechos fundamentales. Asimismo, VARAS (2010), pp. 348-349, considera que, respecto de ciertas materias, y a medida que la madurez necesaria se va alcanzando, son los propios menores los que van haciéndose dueños de la capacidad de decidir por sí mismos y, con ello, van desplazando la representación que hasta antes de ese punto de madurez ostentaban sus padres, con lo que esa autonomía progresiva constituye una frontera, difusa pero cierta, a tal derecho de representación. También LOVERA (2009), pp. 218-219, entiende que el reconocimiento de la titularidad de derechos debe ir acompañado de una teoría de la autonomía. En caso contrario, apunta este autor, si el interés superior del niño significa sólo reconocimiento de titularidad de derechos, pero para que se configuren y protejan desde fuera de los niños, niñas y adolescentes, el principio es irrelevante. Finalmente, EsPEJO y LATHROP (2015), p. 411, refiriéndose al derecho a la identidad, manifiestan que los niños, niñas y adolescentes son titulares de todos los derechos humanos, no debiéndose excluir, como afirma RAVETLLAT (2018) pp. 428-429, aquellos colectivos más afectados por la discriminación social, como la comunidad LGBTI. Concluyen su exposición constatando que no reconocer este derecho fundamental a las personas menores de edad implicaría una distinción no justificada, y en este sentido discriminatoria, entre adultos y niños, niñas y adolescentes en el ejercicio de sus derechos de la personalidad.
} 
Parece que negar la capacidad de ejercicio en el espacio de los derechos de la personalidad cuando el sujeto, a pesar de su edad cronológica, reúne las condiciones intelectivas y volitivas suficientes para ejercitarlos por sí, se torna en una plausible vulneración a la dignidad y al libre desarrollo de la personalidad del individuo ${ }^{24}$, reconocidos en el artículo $1^{\circ}$ de la Constitución chilena como valores superiores del sistema normativo ("Las personas nacen libres e iguales en dignidad $y$ derechos $\left.{ }^{\prime \prime}\right)^{25}$.

Efectivamente, se ha discutido si es aplicable en el campo de los derechos de la personalidad la distinción entre capacidad de goce y capacidad de ejercicio, ya que el goce o ejercicio de estos derechos es personal ${ }^{26}$. De ahí que difícilmente pueda hablarse en este entorno de auténtica representación legal, matizándose mucho esta representación o configurándose más bien como una asistencia o una actuación de los progenitores o tutores en cumplimiento de su deber de velar por el niño, niña o adolescente, especialmente justificada cuando se trate de evitarle un perjuicio ${ }^{27}$.

Sentado lo anterior y en consonancia con el principio del favor filii, la puesta en acción de los derechos de la personalidad por sus legítimos titulares sólo cabe limitarla cuando su voluntad de activarlos sea contraria a intereses preponderantes en atención al pleno desarrollo de su personalidad ${ }^{28}$, de la misma forma

\footnotetext{
${ }^{24}$ Para GIL (2015), p. 28, la personalidad del individuo se funda en esos valores superiores de la dignidad y la libertad, configurándose la misma como un valor unitario situado en el epicentro de todo nuestro ordenamiento jurídico.

25 En este sentido, Otarola (2017), p. 261, nos recuerda que, con relación a la dimensión del libre desarrollo de la personalidad como autonomía, ésta es el primer momento de la libertad, pues corresponde a la intención de realizar aquello que se desea conseguir; posteriormente, prosigue la mentada autora, en virtud de la libertad de opción habrá que elegir los medios para lograrlo. Lo anterior conduce a que los asuntos que le atañen a la persona solo pueden ser decididos por ella, dado que su determinación supone que previamente ha realizado una elección. También es de la misma opinión ANDREU (2013), p. 73, al sostener se puede observar que el reconocimiento progresivo de capacidad de las personas menores de edad se produce sobre todo en el ámbito personal, encontrándose mucho más limitado en los aspectos patrimoniales.

${ }^{26}$ No obstante, no hay que olvidar que los derechos de la personalidad, junto a su aspecto puramente personal, pueden presentar una vertiente patrimonial que puede ser objeto de negocio jurídico, requiriéndose entonces sí la intervención de los representantes legales.
}

27 Andreu (2013), p. 70. Corrobora esta línea de pensamiento Santos (2011), p. 64, quien argumenta que, dado que el núcleo básico de los derechos de la personalidad es la libertad y la dignidad de la persona, y su ejercicio contribuye al libre desarrollo de la personalidad, debe permitirse a todo individuo tomar sus propias decisiones en este campo siempre que tenga el suficiente discernimiento para comprender el acto que realiza. Para el eficaz ejercicio de los derechos de la personalidad, basta pues que el titular de los mismos tenga lo que se viene denominando capacidad natural -raciocinio-.

${ }^{28}$ Estamos pensando, ad exemplum, en la posible afectación de un niño, niña o adolescente por trastornos de conducta alimentaria, e incluso en un consumo querido y consciente de ciertas sustancias 
que se puede limitar la voluntas de sus representantes cuando su intervención sea contraria a los intereses del niño, niña o adolescente ${ }^{29}$.

Pues bien, es precisamente en ese contexto en el que emerge con fuerza la idea de adoptar el criterio de la madurez suficiente, el autogobierno o la capacidad natural, como pauta a seguir para delimitar el ejercicio autónomo de los derechos de la personalidad, evitándose con ello que la persona que no ha alcanzado todavía la mayoría de edad sea simplemente titular del derecho, pero no pueda, en cambio, ejercitarlo. De este modo, la regla general se torna en que la niña, niño o adolescente que presente suficiente madurez pueda disponer libremente de su derecho ${ }^{30}$.

Dicho lo anterior, es relevante apuntar que ante ese nuevo escenario la cuestión se circunscribe en concretar qué se entiende por ostentar madurez suficiente, pues nos encontramos ante un concepto jurídico indeterminado en torno al cual no existe una definición legal unificada. Cada niño o niña es diferente y, por ende, es muy difícil establecer cuándo ostenta o no la capacidad de ejercicio necesaria, debido a su desarrollo intelectual, para poder ser dueño de su propia persona ${ }^{31}$.

Por nuestra parte, consideramos que una persona menor de edad detenta la madurez suficiente o el autogobierno -capacidad natural- cuando demuestra tener la suficiente aptitud psíquica para la válida y efectiva prestación del consentimiento requerido para el ejercicio de un derecho -en nuestro caso, el derecho a la vida o el derecho a la integridad corporal-, así como para asumir las consecuencias que para el desarrollo de su libertad futura tenga esa disposición de voluntad. En suma, el individuo, además de congregar las facultades necesarias para emitir conscientemente una declaración de voluntad -la de autorizar

psicotrópicas, situaciones todas ellas que, por definición, entrañan una disminución o incluso una desaparición de la capacidad natural, por lo que son contrarias a la dignidad y al libre desarrollo de la personalidad del individuo que es, in fine, el objetivo último al que se pretende atender.

${ }^{29}$ En definitiva, como lo establece BARCiA, "el interés superior del niño actúa como un principio que delimita las facultades y deberes de los padres con relación a los hijos". BARCIA (2018), p. 481.

30 Lorente (2017), p. 92; Ravetllat (2017), pp. 30-44; Bartolomé (2015), pp. 80-104, y Lama (2006), pp. 45-56. También es de la misma opinión Moreno (2015), p. 140, cuando apunta que el objetivo de la legislación de infancia es dar un mayor protagonismo a la niñez, que sean personas implicadas activamente en la sociedad, y por lo tanto que en los supuestos en los que la persona cuente con la suficiente madurez pueda llegar a elegir. Para saber si se da esta condición, habrá que valorar cada caso de forma individual, escuchando al niño, niña o adolescente, para poder decidir si tiene el suficiente desarrollo emocional para poder obrar con plena capacidad.

31 Moreno (2015), p. 137. 
un determinado tratamiento o intervención facultativa en su persona-, deberá asimismo conocer cuáles son los efectos jurídicos derivados de la misma ${ }^{32}$.

De acuerdo con lo establecido ut supra, es lógico sostener que el mayor o menor grado de capacidad natural que presenta un individuo depende directamente de su evolución volitiva y cognoscitiva. Ciertamente, como acertadamente se ha encargado de poner de manifiesto parte de nuestra doctrina, el concepto abstracto y subjetivo del discernimiento cristaliza en una noción de naturaleza relativa e indeterminada, en la medida en que un sujeto puede mostrar juicio o raciocinio bastantes para realizar determinados actos y no, en cambio, para concluir otros, pues esa aptitud está condicionada por los caracteres y consecuencias del derecho de cuyo reconocimiento se trate ${ }^{33}$.

En esa misma línea se encuentra el Código Civil chileno, de consabida influencia francesa por lo que a estas cuestiones se refiere -apartándose con ello de las tesis más propias del derecho germánico-- Tal circunstancia se traduce en que el texto de Andrés Bello ha obviado, desde sus orígenes, la tendencia de afirmar o acordar una barrera cronológica que determine o presuma la adquisición de la capacidad natural ${ }^{34}$-la calificada como la edad de la razón ${ }^{35}$-; habrá, pues, que atenerse a la específica demostración, arbitrada caso por caso, de la concurrencia o falta de conocimiento suficiente para efectuar, por y para sí, una precisa actuación con plena relevancia jurídica. A estos efectos, se ponderará adecuada y debidamente tanto la edad de la persona como la naturaleza y trascendencia legal del acto pretendido, así como los usos sociales predicables al caso concreto ${ }^{36}$.

32 Díaz (2010), p. 276, y Sánchez (2003), pp. 956-957. Por su parte, Gete-Alonso (2005), p. 3, entiende que los conceptos plena capacidad natural y autogobierno no son exclusivos del estado de la mayoría de edad, ya que se reconoce un importante poder autónomo a la persona menor de edad.

33 Por poner un ejemplo, es diferente la capacidad necesaria para ejercitar el derecho a la libertad religiosa que la precisa para ser considerado como hábil para ser oído por la autoridad judicial en un proceso de separación o divorcio. Inclusive, sin desplazarnos del ámbito de acción de un mismo derecho, la aptitud o habilidad indispensables pueden variar en atención a la naturaleza concreta del hecho y a su trascendencia y resultados. Así, pensando nuevamente en el derecho a la libertad religiosa, no se exige idéntica competencia para llevar a cabo un acto de culto que para rechazar un tratamiento médico por motivos de credo.

${ }^{34}$ BARCIA (2016), p. 218, sostiene que ya en el Código de Bello, en su versión original, se entendía que la patria potestad no operaba respecto de lo que hoy denominamos derechos de la personalidad. Así, no se admitía la representación legal para contraer matrimonio a nombre del hijo, reconocer a un nieto, testar por el hijo, etc.

35 WeILL Y TeRRÉ (1978), p. 812.

${ }^{36}$ RavetLlat (2016b), pp. 213-224. Una crítica muy acertada a nuestro entender es la vertida por Gil (2015), p. 92, quien afirma que en la práctica, cuando deben resolver una controversia, los jueces suelen acudir a un criterio objetivo como es el de la edad, en lugar de fijarse en aquellos otros más 


\subsection{Antecedentes al principio de la capacidad progresiva en el ámbito sanitario: La Gillick competence a escena}

Analizada la noción de la capacidad natural como criterio esencial para el ejercicio de los derechos de la personalidad -entre ellos el derecho a la vida y a la integridad corporal- por parte de las personas menores de edad, desarrollamos en el presente apartado el conocido Caso Gillick, suscitado ante los tribunales del Reino Unido a mediados de los años ochenta del pasado siglo, por tratarse éste de uno de los antecedentes más claros del actual sistema de delimitación de la autonomía sanitaria imperante en nuestro ordenamiento jurídico ${ }^{37}$.

En el ordenamiento jurídico inglés, la figura de la denominada Gillick competence surgió a partir de leyes sobre anticoncepción, para evitar la contradicción existente entre las disposiciones generales y la legislación penal. En la normativa penal británica (de inicios de los años ochenta) se consideraba delictiva toda relación sexual con personas menores de dieciséis años, por lo que empezó a plantearse el dilema de la distribución de anticonceptivos en individuos que no hubieran alcanzado aún la mayoría de edad.

Paralelamente, por parte del Departamento de Salud se emitió una resolución sobre el uso de preservativos por los adolescentes que no hubieran cumplido todavía la edad de los dieciséis. En cierta medida, se aconsejaba a los facultativos la necesidad de proveer estos elementos cuando fueran requeridos, pero se añadía que en lo posible debía obtenerse el consentimiento de los progenitores. La señora Victoria Gillick, madre de cinco niñas adolescentes, exigió que las autoridades locales le asegurasen que sus hijas no iban a recibir anticonceptivos sin su expreso consentimiento. Como la Administración no atendió su petición, se planteó la

\footnotetext{
subjetivos relacionados no sólo con la madurez, sino también con otro tipo de circunstancias que, sin duda, determinan la consideración sobre el otorgamiento de su necesario consentimiento, como pueden ser la formación o incluso el entorno social.

37 Este caso es citado por la mayor parte de la doctrina anglosajona y europea continental que ha tratado sobre el asunto. En la doctrina anglosajona destacan EEKELAR (1998), p. 61, y FELDMAN (1993). A título de ejemplo, en la doctrina europea continental se hacen eco del mismo DomínGuez (2007), p. 359; Rivero (2007), pp. 152-153; SANTOS (2011), p. 65, y LAMA (2006), pp. 308-309. Otro claro antecedente de la toma en consideración de las personas menores de edad en el marco de las decisiones sanitarias lo encontramos en la conocida como doctrina del menor maduro. Ésta surgió en los Estados Unidos, a partir de los años 70 del pasado siglo, como consecuencia de las demandas incoadas por los progenitores contra los facultativos que atendían a sus hijos e hijas adolescentes sin su conocimiento. En 1973, la Academia Americana de Pediatría elaboró un documento intitulado Model Act Providing for consent of minors fer health services, donde, entre otras cuestiones, se recogía la posibilidad de que una persona menor de edad pudiera dar su consentimiento para recibir asistencia médica cuando fuera capaz de tomar decisiones racionales y dicha asistencia pudiera verse comprometida por el hecho de informar a sus progenitores. BARTOLOMÉ (2015), pp. 198-199.
} 
cuestión ante los tribunales, argumentando que la entrega de anticonceptivos a personas menores de edad interfería en el ejercicio de la patria potestad.

La Cámara de los Lores en el caso Gillick contra el Hospital de West Norfolk, el Área de Salud de Widsbech y el Departamento de Salud ${ }^{38}$, rechazó en 1986 su pretensión señalando que los derechos de los padres existen para el beneficio de sus hijos e hijas y para permitirles cumplir sus deberes, y que el derecho de los representantes legales a elegir si sus representados seguirán o no un determinado tratamiento médico concluye cuando éstos últimos están en condiciones de comprender la opción propuesta ${ }^{39}$.

A raíz de este conocido pronunciamiento jurisprudencial, se alude a la competencia Gillick para referirse al caso de los adolescentes sometidos a responsabilidad parental que son perfectamente capaces de adoptar decisiones autónomas en todo aquello que concierna a su salud, de manera que serán ellos personalmente quienes emitan su consentimiento, y no sus legítimos representantes.

Esta doctrina jurisprudencial fue acogida poco después por la Children's Act, Section 8 (1), Family Law Reform Act 1989, en virtud de la cual "el consentimiento de un menor de dieciséis años a un tratamiento quirúrgico, médico o dental, que, sin dicha autorización constituiría una intromisión a su esfera personal, será tan válido como si fuera mayor de edad; y cuando un menor, de acuerdo con lo establecido en esta sección haya otorgado un consentimiento válido, no será necesario obtener otro consentimiento de su progenitor o representante". La ley ha proporcionado, por ende, un criterio bien definido, en virtud del cual al consentimiento de un adolescente de dieciséis años se le reconoce la misma eficacia que al emitido por un mayor de edad, incluso en el supuesto de que rechace un examen o un tratamiento psiquiátrico ${ }^{40}$.

\subsection{El derecho a la información asistencial}

La premisa inicial para que el consentimiento del paciente sea válido es que éste haya recibido previamente una información adecuada, puesto que

\footnotetext{
${ }^{38}$ Caso Gillick versus West Norfolk and Widsbech Area Health Authority (1984). The Law Reports Appeal Cases 112, (1985) 3 All England Law Reports, 402.

${ }^{39}$ Otro caso sonado es el de Hannah Jones, la niña inglesa de trece años que, apelando a su propia dignidad, rechazó en el año 2008 el trasplante de corazón que podía prolongar su vida. Hannah tuvo leucemia a los cinco años, enfermedad que le provocó una grave lesión de corazón. La única forma de prolongar su vida era el trasplante, cuyos resultados eran medicamente inciertos, porque el tratamiento posterior para evitar el rechazo podía provocar una reaparición de la leucemia. La muchacha, apoyada por sus padres, decidió renunciar al trasplante, lo que, finalmente, fue admitido por las autoridades británicas. El caso Hannah generó un intenso debate en la opinión pública sobre la competencia de los adolescentes para tomar decisiones irreparables sobre su vida y salud.
}

40 López-Chapa (2007), pp. 123-125. 
para decidir libremente es preciso tener conocimiento de la situación, las alternativas, las contraindicaciones, los riesgos y las posibles consecuencias que de ello puedan derivarse.

Este deber de información del paciente se erige como una de las responsabilidades asumidas por los médicos y es requisito previo a todo consentimiento, constituyendo un presupuesto y un elemento esencial de la lex artis para llevar a cabo cualquier actividad facultativa. En otras palabras, el deber de informar se configura como parte integrante de la actuación asistencial y está incluido dentro de la obligación de medios asumida por el equipo médico. Además, y a pesar de que ello no se diga expresamente en la norma, la información que ha de proporcionar el facultativo no se agota en un único acto, sino que es un deber de tracto continuado ${ }^{41}$.

La Ley $N^{\circ} 20.584$ dedica los artículos 8 a 11 al derecho a la información del paciente ${ }^{42}$. Así, estos preceptos reconocen a los pacientes el derecho a conocer, en cualquier intervención asistencial, toda la información obtenida sobre la propia salud, así como, aunque no se enuncie expresamente en la norma, a que se respete, en su caso, su voluntad de no ser informados ${ }^{43}$.

Un aspecto particularmente importante al que debe prestar especial atención el facultativo a la hora de transmitir la información sanitaria, radica en el hecho de no perder de vista cuáles son las condiciones psicológicas y culturales que el paciente presenta, y procurar, en la medida de lo posible, que éste pueda comprender los beneficios y riesgos que conlleva cada una de las opciones clínicas disponibles ${ }^{44}$. Tan sólo se logrará este objetivo si el equipo sanitario evita el uso de tecnicismos que puedan hacer ininteligible la información que se pretende transmitir $y$, a la vez, trata de aclarar las interrogantes que se susciten,

${ }^{41}$ Abel (2005), p. 43. Esta misma idea la encontramos recogida en González (2005), pp. 1625-1628.

${ }^{42}$ En este sentido, el artículo 10 de la Ley № 20.584, de 2012, hace referencia expresa al derecho de toda persona a ser informada "en forma oportuna y comprensible, por parte del médico u otro profesional tratante, acerca del estado de su salud, del posible diagnóstico de su enfermedad, de las alternativas de tratamiento disponibles para su recuperación y de los riesgos que ello pueda representar, así como del pronóstico esperado, y del proceso previsible del postoperatorio cuando procediere, de acuerdo con su edad y condición personal y emocional".

${ }^{43}$ Esta idea de que el derecho a ser informado abarca la posibilidad de no recibir información alguna sobre el estado de salud de la persona, se contiene, por ejemplo, de manera expresa, en el artículo 10.2 del Convenio del Consejo de Europa relativo a los derechos humanos y la biomedicina, de 1997, también conocido como el Convenio de Oviedo, en el que se estatuye que "toda persona tendrá derecho a conocer toda la información obtenida respecto de su salud. No obstante, deberá respetarse la voluntad de una persona a no ser informada".

${ }^{44}$ De Cossío (2009), p. 458. 
empleando términos comprensibles que el paciente alcance a interiorizar sin mayores problemas.

A tenor de lo apuntado, cuando resulte que el paciente sea una persona menor de edad, el facultativo asume la obligación de informarlo en términos que le resulten verosímiles, adaptando y modulando las explicaciones a su grado de desarrollo intelectivo y volitivo (artículo 14, inciso segundo, de la Ley $\mathrm{N}^{\circ} 20.584$ ).

Otra cuestión relevante con relación al derecho a la información sanitaria del paciente menor de edad es la concerniente a quién ostenta su titularidad. A la luz de la legislación vigente, parece incuestionable que tal prerrogativa se reconoce al propio paciente, pues así lo indica expresamente el artículo 10, inciso primero, de la Ley $N^{\circ} 20.584$, al referirse a "toda persona", sin exclusión alguna por motivos de edad. No obstante, una vez fijada esta regla general, este mismo precepto, en su inciso segundo, auspicia la posibilidad de autorizar al facultativo a informar al representante legal, o, en su defecto, a la persona bajo cuyo cuidado se encuentre el paciente, cuando su condición médica no le permita recibir la información directamente o padezca de dificultades de entendimiento - ad exemplum, por tratarse de una persona de muy corta edad- o se encuentre con alteración de conciencia.

Llegados a este punto, se nos plantea la interrogante sobre si la obligación de informar a los representantes legales o, en su caso, a la persona bajo cuyo cuidado se encuentre el menor, es ineludible o debe combinarse con el respeto al deber del secreto médico y con el derecho a la intimidad del niño, niña o adolescente. Para resolver satisfactoriamente tal cuestión no nos cabe sino acudir a la interpretación teleológica, a la ratio legis perseguida por las disposiciones normativas reguladoras de esta materia ${ }^{45}$.

Efectivamente, el fin último de estos preceptos es proteger la salud y la vida de los niños, niñas y adolescentes posibilitando que los titulares de la responsabilidad parental y, en su caso, quien venga asumir estas funciones, puedan

\footnotetext{
${ }^{45}$ Según entiende LEón (2013), p. 116, a partir de los 14 años, al deber de informar se agrega el de resguardar debidamente la confidencialidad, que siempre es un deber para con el propio paciente. Esa confidencialidad, prosigue dicho autor, debe tener en cuenta el derecho de los padres a saber cuándo se produce una situación grave o que puede poner en grave riesgo la vida o la salud futura de su hijo, pero también el derecho del menor maduro a resguardar algunos aspectos de su conducta que desea tratar solamente con su médico, en una relación de confianza médico-paciente. En un sentido similar se pronuncia BARCIA (2016), p. 215, quien apunta que "se puede considerar que los derechos de la personalidad del niño se configurarán por aquellos derechos que ejerce personalmente, sin mediar representación a través del principio del ejercicio progresivo de sus derechos, pero de una intensidad inferior al encontrarse sujetos a una tutela de protección". No comparte esta idea, en cambio, Domínguez (2014), pp. 31-35, quien considera que la información debe ser proporcionada, en todo caso, a los representantes de las personas menores de edad.
} 
ejercer su facultad de velar por ellos. Este deber se traduce en la necesidad de proteger la dignidad y el libre desarrollo de la personalidad, por lo que, en aras de la adecuada atención a la persona menor de edad, los representantes legales deben conocer aquellas circunstancias relativas a su salud que pueden poner en peligro su apropiado crecimiento físico y mental ${ }^{46}$.

Amén de lo apuntado, entendemos que la obligación de informar a los representantes legales de la situación médica en la que se encuentra la persona menor de edad no debe interpretarse de forma absoluta, sino en correspondencia con el criterio de protección del sujeto menor de edad que inspira e informa estas instituciones jurídicas, por lo que no se podrá invadir su intimidad cuando no exista riesgo para la salud ${ }^{47}$. Así, en definitiva, debiera distinguirse entre aquellas situaciones médicas que no entrañen peligro grave para la persona menor de edad de aquellas otras que sí lo comportan, pues mientras que en el primero de los casos sólo deberá informarse a sus representantes legales si el sujeto menor manifiesta su consentimiento expreso o tácito al respecto, en el segundo, en cambio, consideramos que sí existe un deber de informar a sus representantes legales, ello incluso en contra de la propia voluntad del menor, pues en este caso debe sacrificarse su intimidad en favor de la protección de su salud.

En realidad, este deber de informar a los progenitores -o persona bajo cuyo cuidado se encuentre el sujeto- va íntimamente ligado con la capacidad de la persona menor de edad para consentir por sí misma en el ámbito de los derechos de la personalidad. En efecto, si el niño, niña o adolescente no reúne madurez suficiente para prestar el consentimiento, serán sus representantes legales quienes reciban la información y decidan sobre el tratamiento, aunque aquél

\footnotetext{
${ }^{46}$ García (2017), pp. 549-553.

47 Este parece ser el criterio, acertado desde nuestro punto de vista, adoptado por la Ley № 20.418, de 2010, que fija normas sobre información, orientación y prestaciones en materia de regulación de la fertilidad. Esta norma (artículo $2^{\circ}$ ) establece la obligación de los funcionarios o facultativos de informar, en forma posterior a la entrega del medicamento, al padre, madre o adulto responsable que la persona menor de edad señale, solo para el caso de que se solicite un método de anticoncepción de emergencia por parte de una menor de 14 años. En los demás supuestos debe primar la confidencialidad, salvo que se detecten situaciones de abuso o violencia, en donde deberá procederse conforme a la normativa vigente (artículo $5^{\circ}$ ). Esta misma interpretación es la ofrecida por el MINISTERIO DE SALUD (2016), p. 1, en su Circular N ${ }^{\circ}$ A15/10, de 2016. En igual sentido, BARCIA (2006), p. 144, se pronunciaba ya con rotundidad, incluso antes de la aprobación de la ley, al afirmar que "si el adolescente, mayor de catorce años, puede tener relaciones sexuales también ha de reconocérsele la capacidad natural para poder exigir y recibir de la autoridad sanitaria la píldora del día después. Esto es evidente, además, en el Derecho chileno, de desde que se reconoce la capacidad de los adolescentes para recibir de las autoridades sanitarias profilácticos, ello sólo deja de manifiesto el reconocimiento de una esfera de madurez e independencia del adolescente, que por tratarse de un derecho de la personalidad, no depende, ni puede estar subordinado a la representación legal como la concibe el Derecho civil patrimonial tradicional".
} 
deberá ser informado y escuchado en función de su grado de raciocinio. Si, por el contrario, la persona menor de edad ostenta capacidad, debería ésta prestar por sí misma la declaración de voluntad y el médico respetar la confidencialidad de su estado de salud si así lo insta el propio individuo, excepto si éste actúa de forma que ponga gravemente en peligro su integridad física y/o psíquica ${ }^{48}$.

De esta suerte, en un caso de contagio del virus de inmunodeficiencia humana en el que una persona menor de edad tenga capacidad para la toma de decisiones autónomas deberemos valorar si la situación médica entraña o no un posible riesgo para su salud. Ciertamente, si se trata de un diagnóstico que con el tratamiento adecuado puede convertirse de hecho en una situación crónica de salud que permita llevar al paciente una vida relativamente normal, es decir, que la vida de la persona menor de edad no peligra de forma inminente, debería priorizarse también su autonomía y su intimidad en la medida en que presente la suficiente madurez intelectual y emocional. En cambio, si se niega a someterse al tratamiento diagnosticado para impedir el desarrollo de la enfermedad, debe entenderse la necesidad de comunicarse la situación a sus representantes legales y que sean éstos quienes decidan, pues sólo así podrán cumplir con su deber de velar por el adecuado desarrollo de sus hijos. En efecto, nos encontramos ante una situación relevante, que pone en peligro la integridad del sujeto, y ante la existencia de un tratamiento con un altísimo porcentaje de probabilidades de éxito, que salvará su vida y le facilitará el bienestar que se está rechazando sin justa causa por el interesado. Ante tal contingencia, la confidencialidad y la autonomía de la persona menor de edad han de ceder ante la necesidad de proteger los bienes jurídicos de la vida y de la salud ${ }^{49}$.

Cuestión diferente es que la persona menor de edad decida no someterse a tratamiento o intervención alguna cuando estamos ante una enfermedad incurable, en fase terminal o incluso con unas posibilidades remotas de éxito del tratamiento que, en cambio, con toda seguridad comportará unos efectos secundarios o perjuicios graves para la misma. Así sucedería, por ejemplo,

\footnotetext{
${ }^{48}$ De la misma opinión es Rulz (2009), p. 81, quien sostiene que la información deberá darse al paciente, aunque éste sea menor de edad, siempre, por supuesto, que el paciente tenga capacidad para entender. Por su parte, Bartolomé (2015), p. 201, entiende que "ante el ejercicio de los derechos de carácter personalísimo, que excluyen la sustitución, parece razonable que este ejercicio no se rija por las reglas generales de capacidad de obrar, sino por la aptitud de su titular para comprender y querer el alcance de sus actos, así como por las condiciones de madurez del individuo. Si bien es cierto que ello no puede significar que todo menor (véase el caso extremo de los bebés), pueda decidir sobre cuestiones tan trascendentes que afectan a su propia salud o desarrollo vital".

49 Nos recuerda Pérez (1997), p. 155, que sólo en el caso en que se compruebe que priman otros deberes frente al derecho a la intimidad del donante y correspondiente deber de secreto, el no respeto del mismo dejará de acarrearle cualquier responsabilidad.
} 
cuando la persona menor de edad ha desarrollado SIDA y está en fase terminal o cuando nos hallamos ante un tumor maligno cuyas posibilidades de curación tras intervención facultativa y tratamiento adecuados son escasas. En estos casos, entendemos, debe primar la confidencialidad y el médico deberá guardar secreto dando por válida la decisión del sujeto menor de edad.

\subsection{La autonomía del paciente menor de edad. El consentimiento informado}

A tenor de lo expuesto en los apartados precedentes, si entendemos la exigencia de requerir el consentimiento informado como una manifestación de la protección de la autodeterminación de los pacientes, cabe concluir que ha de ser el propio paciente o usuario de los servicios sanitarios quien, con independencia de su edad, deba consentir la respectiva intervención médica, pues es él quien mejor conoce sus propias necesidades, prioridades, planes y objetivos $^{50}$. Lo anterior se aplicará siempre y cuando su capacidad de juicio y discernimiento se lo permitan y no se encuentre, en los términos del artículo 15 de la Ley $N^{\circ} 20.584$, ante un supuesto de riesgo vital o de riesgo para la salud pública.

Sobre el consentimiento de las personas menores de edad, cabe adelantar que respecto de la autonomía de los niños, niñas y adolescentes no existe en nuestro ordenamiento un tratamiento uniforme, si no que más bien se presenta como una sumatoria de regulaciones dispersas y en muchos casos contradictorias $^{51}$, distando mucho de la regulación de la capacidad dada en el ámbito civil patrimonial ${ }^{52}$.

Así las cosas, el quid del asunto radica en determinar si jurídica y psicológicamente las personas menores de edad se encuentran en situación de ejercitar libremente sus derechos de la personalidad -y en particular los derechos a la vida, a la autodeterminación y a la integridad física y psíquica-53, o si, por el contrario, también en este ámbito deben actuar imperiosamente por medio de sus representantes legales, de igual forma que se les exige en el ámbito civil patrimonial ${ }^{54}$.

\footnotetext{
50 Galán (2016), pp. 621 y ss.; SánChez (2002), p. 85, y Santos (2001), p. 206. En igual sentido, el francés Le TOURNEAU (2006), p. 312.

51 Domínguez (2016), pp. 106-108.

52 RavetLlat (2015), pp. 741-745.

53 BARCIA (2013), pp. 11-15.

${ }^{54}$ Siguiendo a FAMÁ (2017), pp. 382-386, podemos apuntar que en las legislaciones comparadas se observan tres tendencias a la hora de reconocer el derecho de niños, niñas y adolescentes a tomar decisiones relativas al cuidado de su propio cuerpo: una primera se inclina por no marcar límites etarios para consentir determinados actos médicos, receptando el principio general de la capacidad o
} 
La respuesta a la cuestión planteada no ha estado exenta de conflictos, emergiendo como una de las primeras dificultades la clara exclusión en la creación normativa de otras realidades y hallazgos disciplinarios, abordándose la discusión relativa a niños, niñas y adolescentes casi únicamente desde la perspectiva jurídica ${ }^{55}$.

Una segunda dificultad la encontramos en la reticencia a aceptar como disciplina autónoma del ordenamiento jurídico el calificado como derecho de la infancia y la adolescencia, primando a este respecto una concepción más bien paternalista, que tiende a concebir a los niños, niñas y adolescentes, en contraposición a la categoría de los adultos, como los "todavía no" -todavía no adultos, todavía no responsables, todavía no con los mismos derechos, todavía no dignos de ser tomados en consideración-.

En este punto, cabe subrayar una marcada tendencia que se está planteando en buena parte de los ordenamientos jurídicos occidentales, y también en Chile, la cual apunta claramente hacia una reducción importante en la edad en que se considera competente a las personas, especialmente en el ámbito extrapatrimonial. Se ha debatido, así, si se puede o no entregar directamente a una adolescente la píldora del día después, o si puede asistir sola a la consulta ginecológica, sin adulto alguno que la acompañe, o si el médico puede tratar ciertos aspectos a solas, sin que estén presentes en ese momento los progenitores o representantes legales ${ }^{56}$.

No obstante, otro sector de la doctrina se manifiesta contrario al hecho de que una persona menor de edad pueda libre y autónomamente decidir sobre si aceptar o rechazar un tratamiento o una intervención médica en su propio cuerpo, planteando al respecto que deben ser sus representantes legales los Ilamados a recibir la información y a otorgar el pertinente consentimiento sanitario respecto de una actuación que ha de realizarse en el cuerpo de su representado ${ }^{57}$.

autonomía progresiva, y debiendo examinarse la madurez en cada caso concreto; una segunda vertiente tiende a fijar edades cronológicas inamovibles para prestar el consentimiento para determinados actos médicos, y una tercera opción combina criterios objetivos y subjetivos, de modo que la competencia médica es valorada en función de la edad y madurez del sujeto y de la complejidad del acto médico.

55 Domínguez (2016), p. 112.

56 LEÓN (2012), p. 115.

57 Por todos, véase a Domínguez (2014), pp. 30-35. En este mismo sentido parece pronunciarse el Memorándum A $15 \mathrm{~N}^{\circ}$ 03681, sobre información sensible y consentimiento informado de niños, niñas y adolescentes de Sename, de 27 de diciembre de 2017, al establecerse que "sobre las conductas referidas al consentimiento informado, cabe señalar que la regla general para la autorización de procedimientos o tratamientos vinculados a la atención de salud de personas menores de 18 años de edad es que ésta sea realizada por su representante legal, el que generalmente será su padre o madre. Sin perjuicio de que en ciertas materias, la ley ha establecido reglas especiales que han permitido, con 
Ahora bien, atendiendo a nuestro posicionamiento, es decir, defender que sí deben ser oídas las personas menores de edad y, que bajo ciertos respectos pueden, además, participar autónomamente en la toma de decisiones relacionadas con su integridad, vida y salud, ejerciendo libremente aquellos derechos de la personalidad respecto de los cuales son titulares exclusivos ${ }^{58}$, creemos necesario distinguir entre dos categorías de sujetos que todavía no han alcanzado la mayoridad. Así, en concordancia con lo preceptuado en el artículo 16 , inciso $3^{\circ}$ de la Ley $N^{\circ} 19.968$, de 2004, categorizaremos a las personas menores de 14 años como niños y niñas, y a las mayores de 14 pero menores de 18 como adolescentes. Además, utilizaremos también aportaciones interdisciplinarias procedentes de la bioética y psicología evolutiva, hallazgos que nos permitirán plantear algunas reflexiones sobre los requisitos, la independencia y las consecuencias de las decisiones tomadas por niños, niñas y adolescentes en el ámbito de la medicina terapéutica.

La percepción de las personas menores de edad en las relaciones sociales ha experimentado una notable transformación, pasando desde la clásica noción de incapaz físico y moral, hasta la visión actual, que erige a los niños, niñas y adolescentes como titulares activos de derechos, cuyo razonamiento moral y autonomía se encuentran en un continuo desarrollo y que, debido a su vulnerabilidad, requieren de un especial acompañamiento en los procesos de toma de decisiones ${ }^{59}$.

La descrita evolución social y cultural de la posición de las personas menores de edad se consagra con el acuñamiento del concepto de menor maduro, según el cual "los derechos civiles, subjetivos o de la personalidad se generan en el individuo desde el mismo momento en que éste es capaz de disfrutarlos ${ }^{\prime \prime 60}$. No obstante, aunque a estas personas se les pueda reconocer cierta capacidad de comprensión, es indispensable la presencia de la prudencia como característica de los procesos de toma de decisiones en los que participen niños, niñas y adolescentes; en efecto, esta exigencia moral permite ponderar racionalmente

ciertos resguardos, que personas menores de 18 años puedan autorizar por sí mismos ciertos procesos, esto es el caso de materias vinculadas a anticoncepción, incluida la de emergencia, consejería, examen de detección de VIH e interrupción voluntaria del embarazo".

58 Ogando y García (2007), pp. 877-883, y Pinto y Gulfo (2013), pp. 144-165. Además, tal y como enuncia Lovera (2017), p. 168, "debe avanzarse en aceptar que la autonomía de los adolescentes se respeta, primero, cuando se les reconoce el goce de derechos constitucionales y, segundo, cuando son ellas y ellos mismos quienes deciden cómo ejercer esos derechos".

59 Pinto y Gulfo (2013), p. 146.

${ }^{60}$ Ogando y García (2007), p. 878. 
la consideración efectiva sobre riesgos y beneficios derivados de las decisiones individuales ${ }^{61}$.

Ahora bien, ateniendo, desde una perspectiva psicológica, a la prudencia como elemento clave en el desarrollo de la madurez en niños, niñas y adolescentes, sumada a la normativa nacional e internacional vigente en nuestro ordenamiento, con especial referencia al principio de capacidad progresiva del individuo y al derecho de los niños, niñas y adolescentes a ser oídos, nos parece interesante distinguir entre asentimiento y consentimiento sanitario, calificación que dependerá de la mayor o menor presencia de los factores mencionados.

Hablaremos, así, de asentimiento sanitario respecto de los niños y niñas menores de 14 años, donde, debido al proceso de desarrollo y madurez en el que pueden encontrarse, la exigencia de participar autónomamente se traduciría en que, ante decisiones que les pudieran afectar, el personal sanitario debe considerar su opinión, aunque ésta no sea vinculante ${ }^{62}$. Aquí cabe plantear una presunción iuris tantum de inmadurez, por lo que quien quiera desvirtuarla deberá acreditar la respectiva madurez de la niña o niño para que su decisión sea vinculante para el facultativo.

Por su parte, en el caso de los adolescentes, desde una perspectiva bioética se ha entendido que la aparición de la autoconsciencia como parte de su desarrollo psicológico les permite la adopción de un papel más activo en el proceso del consentimiento informado ${ }^{63}$, pudiendo, en consecuencia, las personas mayores de 14 años tomar válidamente decisiones de forma autónoma respecto de intervenciones que afectarán su salud e integridad. En este caso, a diferencia del anterior, se generará la presunción iuris tantum de que el individuo, una vez alcanzados los 14 años de edad, cuenta con la aptitud intelectiva y volitiva necesaria para prestar por sí el consentimiento informado.

\section{El consentimiento informado de personas menores de edad en la Ley No 20.584, de 24 de abril de 2012}

\subsection{Antecedentes}

Cabe destacar que la actual Ley $\mathrm{N}^{\circ} 20.584$ es el resultado de una serie de proyectos previos - presentados todos entre los años 2000 y 2006 - que culminaron con el proyecto presentado por el ejecutivo el 26 de julio de 2006 -Boletín $N^{\circ} 4.398-11-$, proyecto que luego de importantes transformaciones, algunas de

\footnotetext{
61 Sabatello (2009), p. 166.

62 Del Río (2010), p. 65.

63 Rueda (2008), p. 9.
} 
ellas precisamente sobre la capacidad de las personas menores de edad para aceptar o rechazar un tratamiento terapéutico, se transformó en la normativa que hoy regula los derechos y deberes que tienen los sujetos en relación con acciones vinculadas a su atención en salud.

Sobre el proyecto primitivo, nos parece interesante destacar que dentro de los principios inspiradores de la normativa el número $4^{\circ}$ se refería, específicamente, al "Respeto de los menores de edad", señalando al respecto que "Recogiendo lo que convenios y declaraciones internacionales obligan en materia de respeto de los menores de edad, el proyecto reconoce en los menores su calidad de sujetos de derechos, distinguiendo entre los menores de catorce años y los mayores de esa edad para efectos de la participación que les corresponda en las decisiones que involucran su propio cuerpo y su salud. Así, respecto de los menores de catorce años, aun cuando su voluntad es subrogada por sus representantes legales, se hace necesario que sean informados y consultada su opinión, respetando sus condiciones de desarrollo psíquico, competencia cognitiva y situación personal. En el caso de mayores de catorce y menores de dieciocho años, el proyecto exige que ellos sean informados directamente por el profesional tratante; también se garantiza que no se pueda intervenir su cuerpo sin su consentimiento. Sin embargo, se regula el caso en que dicho profesional estime que existe una situación de grave riesgo para la salud o la vida del menor, informe a los padres y requiera su opinión, permitiendo que en casos de duda, consultar al comité de ética que corresponda".

Otro punto a destacar del proyecto presentado por el ejecutivo es la redacción del original inciso $2^{\circ}$ del artículo 16, precepto que se ubicaba en el párrafo $5^{\circ}$, titulado "De la autonomía de las personas en su atención de salud", y que servía de complemento a los artículos $8^{\circ}$ y 14 , proponiendo una regulación bastante novedosa, que reconocía expresamente la capacidad para tomar decisiones en materia de asistencia sanitaria a los mayores de 14 años y menores de 18 , y respecto de los niños y niñas menores de 14 establecía claramente el derecho de estos a ser oídos en dicho ámbito asistencial ${ }^{64}$.

\footnotetext{
64 "Artículo 16: Tratándose de personas con dificultades de entendimiento o con alteración de conciencia, o que carezcan de capacidad para expresar su voluntad por causa de enfermedad mental, certificada por un médico cirujano, igualmente se les deberá informar y consultar su opinión, sin perjuicio que la decisión temporal o definitiva, según corresponda, deberá ser adoptada por quien tenga su representación legal, si careciese de él, por quien haya sido constituido como su apoderado para fines de su tratamiento y, en último caso, por la persona a cuyo cuidado se encuentre.

En el caso de los menores de dieciocho años y mayores de catorce, la expresión de voluntad deberá ser personal, sin perjuicio de lo cual, si el médico tratante estima que la situación del menor implica grave riesgo para su salud o su vida, podrá, con consulta al comité de ética que corresponda, consultar directamente a los padres o representantes legales. En caso de que la voluntad manifestada por el menor difiera de la voluntad manifestada por su representante, será aplicable, en lo que corresponda, lo dispuesto en el artículo 19. A los menores de catorce años de edad igualmente se les deberá consultar
} 
Trayendo a colación parte de la discusión parlamentaria, cabe observar que buena parte del debate se centró particularmente en si los progenitores del niño, niña o adolescente debían o no ser informados y si éste podía oponerse a que cierta información terapéutica le fuera comunicada a sus representantes legales. Al respecto, es el inciso segundo del artículo $8^{\circ}$ el apartado que suscitó mayor discusión, pasando a un segundo plano el importante inciso segundo del artículo 16, que era el que consagraba expresamente la autonomía de los adolescentes en materia de intervenciones terapéuticas ${ }^{65}$.

En este punto, relevante resulta apreciar que la redacción original del inciso segundo del artículo 16 se mantuvo inalterado (solo con modificación de numerales, pasando posteriormente a ser el artículo 17) hasta la sesión de 18 de mayo de 2011, donde, por unanimidad y con argumentos que atacaban el primer inciso de dicho precepto y no el relevante inciso segundo, se decide suprimir completamente la importante disposición ${ }^{66}$.

su opinión, sin perjuicio que la decisión definitiva corresponderá a los representantes legales". Texto proyecto de ley que regula los derechos y deberes que tienen las personas en relación con acciones vinculadas a su atención en salud. Boletín № 4.398-11.

65 "Artículo $8^{\circ}$ : Toda persona tiene derecho a ser informada, en forma oportuna y comprensible, por parte del médico u otro profesional tratante, dentro del ámbito que la ley autorice, acerca del estado de su salud, posible diagnóstico de su enfermedad, las alternativas de tratamiento disponibles para su recuperación y los riesgos que ello pueda representar, así como el pronóstico esperado, y el proceso previsible del postoperatorio cuando procediere, de acuerdo con su edad, condición personal y emocional.

A los menores de dieciocho años de edad y mayores de catorce se les deberá informar directamente. Sin perjuicio de lo anterior, si el médico tratante estima que la situación del menor implica grave riesgo para su salud o su vida podrá, con conocimiento del menor, informar directamente a los padres o representantes legales o la persona que lo tenga bajo su tuición o cuidado. En caso de duda acerca de la gravedad o de la pertinencia de informar a los padres o representantes y el menor no esté de acuerdo con que éstos sean informados, deberá consultar al comité de ética que corresponda. A los menores de catorce años de edad igualmente se les deberá informar, atendiendo las condiciones de desarrollo psíquico, competencia cognitiva y situación personal, sin perjuicio que se informe directamente, en los términos del inciso anterior, a los representantes legales". Texto proyecto de ley que regula los derechos y deberes que tienen las personas en relación con acciones vinculadas a su atención en salud. Boletín № 4.398-11.

66 "Artículo 17: Tratándose de personas con dificultades de entendimiento o con alteración de conciencia, o que carezcan de capacidad para expresar su voluntad por causa de enfermedad, certificada por un médico cirujano, igualmente se les deberá informar y consultar su opinión, sin perjuicio que la decisión temporal o definitiva, según corresponda, deberá ser adoptada por quien tenga su representación legal o, en su defecto, por el apoderado designado para fines vinculados a su tratamiento y, en último caso, por la persona a cuyo cuidado se encuentre.

Los mayores de catorce años de edad y menores de dieciocho expresarán su voluntad personalmente. Sin perjuicio de ello, los padres o representantes legales deberán ser también consultados al respecto. Sin embargo, si el menor se opone a que ellos sean consultados, el profesional tratante podrá acceder a dicha petición si estima que la situación del menor no implica grave riesgo para su salud o su vida. Cuando el profesional tratante tenga dudas acerca de las situaciones anteriormente descritas o si el 
Es del caso precisar que, en la redacción definitiva de la normativa que regula los derechos y deberes que tienen las personas en relación con acciones vinculadas a su atención en salud, se eliminaron prácticamente todas las referencias a las personas menores de edad; de un total de cinco preceptos que hacían referencia a los menores de edad en el proyecto original, en la actual ley solo se contempla una referencia, en el actual artículo 17.

\subsection{Hacia una relectura de la Ley $N^{\circ} \mathbf{2 0 . 5 8 4}$ respecto de pacientes menores de edad}

Sin perjuicio de lo anotado precedentemente, si se tienen en consideración los principios que se tuvieron a la vista al momento de la tramitación del proyecto de ley, la normativa y principios consagrados en la Convención sobre los Derechos del Niño, con especial referencia al principio de capacidad progresiva del individuo o del ejercicio progresivo de los derechos de la infancia y adolescencia ${ }^{67}$, nos parece plausible interpretar los artículos 10 y 14 de la

menor se opone a que dicha opinión sea requerida, corresponderá al comité de ética decidir acerca de la pertinencia de que el médico efectúe la consulta. Asimismo, dicho comité deberá ser consultado, en caso de que exista discrepancia entre la voluntad expresada por el menor y la opinión de sus padres o representantes. Los menores de catorce años de edad también deberán ser consultados, atendiendo sus condiciones de desarrollo psíquico, su competencia cognitiva y su situación personal, sin perjuicio que la decisión definitiva corresponderá a sus padres o representantes legales". Texto proyecto de ley que regula los derechos y deberes que tienen las personas en relación con acciones vinculadas a su atención en salud. Boletín No 4.398-11

El honorable senador señor Walker, don Patricio, manifestó que, tratándose de un menor con dificultades de entendimiento o con alteración de conciencia o que carece de capacidad para expresar su voluntad por causa de enfermedad, es obvio que corresponde consultar a sus padres o representantes legales. En rigor, debió ser planteado como artículo aparte, pero ya se resolvió el fondo de este asunto, en cuanto a no prescindir del parecer de quienes tienen el deber de cuidado y formación de los menores de edad, lo que debe llevar a la eliminación de este inciso, para guardar la debida correspondencia con los acuerdos anteriores.

El honorable senador señor Espina propuso suprimir también el inciso primero del artículo 17, porque altera las normas generales sobre representación de incapaces. Además, crea una situación imposible, como es la obligación de informar y pedir opinión, antes de prestarle atención médica, a alguien con dificultades de entendimiento o con alteración de conciencia o que carece de capacidad para expresar su voluntad por causa de enfermedad. Llamó a confiar en el criterio del profesional tratante.

El señor ministro de Salud se manifestó partidario de eliminar el inciso primero, porque pone en riesgo la salud de las personas.

Por acuerdo unánime de los miembros presentes, honorables senadores señora Rincón (con dos votos) y señores Espina (con dos votos), Larraín, don Hernán, Rossi, Uriarte y Walker, don Patricio (con dos votos), se suprimió el artículo 17.

67 Principio, por lo demás, expresamente reconocido en el artículo séptimo del proyecto de ley que regula el sistema de garantías de los derechos de la niñez (Boletín 10315-18), el cual señala que "Todo niño, en conformidad a la ley, podrá ejercer sus derechos por sí mismo, en consonancia a la evolución de sus facultades, su edad y madurez". También tomar en consideración las Observaciones Generales 
Ley $\mathrm{N}^{\circ} 20.584$ en el sentido de permitir a los adolescentes -mayores de 14 y menores de 18- manifestar válidamente su voluntad en orden a consentir o rechazar una determinada intervención médica.

En efecto, el citado artículo 14 expresa en su inciso $1^{\circ}$ que "Toda persona tiene derecho a otorgar o denegar su voluntad para someterse a cualquier procedimiento o tratamiento vinculado a su atención de salud, con las limitaciones establecidas en el artículo 16". Al respecto, no encontramos razón alguna para excluir a los adolescentes del ejercicio de esta prerrogativa relacionada directamente con la tutela de derechos de la personalidad a los adolescentes, principalmente por tres argumentos: en primer término, el mentado precepto se refiere a "toda persona", sin excluir en razón de la edad a los mayores de 14 y menores de 18 años, precepto que por lo demás es concordante con la amplia e incluyente redacción del artículo 55 de nuestro Código Civil, el que reconoce como personas a todos los individuos de la especie humana, sin distinción de sexo, edad, estirpe o condición. En segundo lugar, desde la perspectiva de la titularidad de derechos de la personalidad, tampoco hay discusión en que las personas menores de edad puedan ser titulares de los derechos: a la vida, a la autodeterminación, a la integridad física y psíquica, a la salud, entre muchos otros. Respecto de su ejercicio, no debemos confundir la plena capacidad de ejercicio patrimonial, que estructuralmente se adquiere con la mayoría de edad, con la capacidad para ejercer los derechos de la personalidad, la cual se presenta necesariamente con carácter de personalísima. Por último, y en relación con el argumento anterior, es necesario distinguir con nitidez el ejercicio del consentimiento informado por parte del paciente del consentimiento contractual clásico. La diferencia es mayor, como ya lo adelantamos. El que se requiera la voluntad del paciente para aceptar o rechazar un tratamiento no tiene por finalidad alguna el arribo a un acuerdo de carácter contractual entre partes; por el contrario, el ejercicio de esta potestad por parte del paciente ${ }^{68}$, se manifiesta como una herramienta de protección de la autodeterminación de dicho paciente, por lo que será este paciente, quien, conociendo sus planes, objetivos y necesidades, habrá de ejercer soberanamente tal potestad.

Por otra parte, el artículo 10 de la Ley № 20.584 viene a reforzar la idea de la autonomía progresiva de las personas menores de edad al consagrar el

elaboradas por el Comité de los Derechos del Niño, en particular las número 20 y 12, referidas a los derechos de los adolescentes y al derecho del niño a ser escuchado, respectivamente. Comité de los Derechos del Niño (2016) y Comité de los Derechos del Niño (2009).

${ }^{68}$ Prerrogativa que en nuestra normativa sanitaria tiene una doble consagración. Por una parte, se configura como un derecho para el paciente desde la perspectiva de su ejercicio y, por otra parte, se configura para el facultativo como una obligación que integra la respectiva lex artis, parámetro que servirá para medir si su actuar fue diligente o negligente. 
derecho de toda persona, sin exclusión, a ser informada. Continúa el precepto en comento exigiendo que la información que ha de ser entregada al paciente, junto con ser oportuna, debe ser comprensible en razón de la edad, condición personal y emocional del paciente ${ }^{69}$, texto que nos permite sostener que esta información, en los casos en que su receptor sea una persona menor de edad, deberá adecuarse a las especiales características del niño, niña o adolescente que en claro ejercicio de su autonomía ha de asentir, consentir o rechazar un tratamiento, en los términos permitidos por la propia norma legal.

Por último, desde la perspectiva de la acreditación del estado de madurez que le permita al adolescente válidamente tomar una decisión sobre su propio cuerpo en materia sanitaria, útil resulta plantear que se les reconozca a los mayores de 14 años una especie de presunción iuris tantum de plena capacidad para ejercitar libremente aquellos derechos de la personalidad respecto de los cuales son titulares, como en este caso serían el derecho a la vida, a la salud, a la autodeterminación y a la integridad corporal, entre otros. Por lo tanto, en aquellos casos en que el personal de salud considere que este adolescente no se encuentra capacitado para prestar válidamente su consentimiento por considerarlo inmaduro, nos parece razonable imponer a dicho personal la carga de proporcionar la evidencia necesaria que permita desvirtuar la citada presunción de madurez.

\section{Bibliografía CitADA}

Aвel LluCh, Xavier (2005): "El derecho de información del paciente como presupuesto del consentimiento informado. Su régimen jurídico en la Ley No 41/2002, de 14 de noviembre, básica reguladora de la autonomía del paciente y de derechos y obligaciones en materia de información y documentación clínica", en: Abel Lluch, Xavier (director), El juez civil ante la investigación biomédica (Madrid, Consejo General del Poder Judicial), pp. 15-126.

Alessandri Rodríguez, Arturo (2004): De los contratos (Santiago de Chile, Editorial Jurídica de Chile).

Andreu Martínez, María Belén (2013): La protección de datos personales de los menores de edad (Cizur Menor, Thomson Aranzadi).

Asensio SÁnCheZ, Miguel Ángel (2012): Patria potestad, minoría de edad y derecho a la salud (Madrid, Dykinson).

69 PARRA (2013), pp. 1578-1583. 
Ataz López, Joaquín (1985): Los médicos y la responsabilidad civil (Madrid, Montecorvo).

Barcia Lehman, Rodrigo (2018): "La evolución de la custodia unilateral conforme a los principios de interés superior del niño y corresponsabilidad de los padres", en: Revista lus et Praxis (Vol. 24, № 2), pp. 469-562.

(2016): “Derechos fundamentales y autonomía progresiva de la infancia", en: Lepin Molina, Cristián, y Gómez de la Torre Vargas, Maricruz (coordinadores), Estudios de Derecho Familiar I (Santiago de Chile, Thomson Reuters), pp. 211-220.

(2013): "La capacidad extrapatrimonial de los niños y adolescentes conforme a sus condiciones de madurez", en: Revista lus et Praxis (Vol. 19, № 2), pp. 3-52.

(2006): "Sobre la capacidad de los adolescentes para recibir la denominada píldora del día después", en: Revista Chilena de Derecho Privado (No 7), pp. 137-158.

BARros Bourie, Enrique (2006): Tratado de responsabilidad extracontractual (Santiago de Chile, Editorial Jurídica de Chile).

BARTOlomé Tutor, Aránzazu (2015): Los derechos de la personalidad del menor de edad. Su ejercicio en el ámbito sanitario y en las nuevas tecnologías de la información y comunicación (Cizur Menor, Thomson Reuters).

Craven-Bartle Lamote de Grignon, Jordi (2005): “La prestación del consentimiento informado por el paciente. Desde las exigencias legales a la práctica médica", en: Abel Lluch, Xavier (director), El juez civil ante la investigación biomédica (Madrid, Consejo General del Poder Judicial), pp. 129-153.

Comité de los Derechos del Niño (2016): "Observación General No 20". Disponible en: http://docstore.ohchr.org/SelfServices/FilesHandler.ashx?en$\mathrm{C}=6 \mathrm{QkG}$ 1 $\%$ 2FPPRiCAqhKb7yhsqlkirKQZLK2M58RF\%2F5F0vH\%2Bg0Be HNYSXI2ulaelW9Y1jn\%2Ba4Z2iaNPMKIJhzvzg\%2BBPHd5dvVM1aQpaih 1nCQKMKsmTkxWuZUDLtwpmjwRZN [visitado el 28.09.2019].

Comité de los Derechos del Niño (2009): “Observación General № 12". Disponible en: https://www.acnur.org/fileadmin/Documentos/BDL/2011/7532. pdf?view=1 [visitado el 28.09.2019].

De Cossio Rodríguez, Patricia (2009): "El consentimiento informado", en: Rivas Vallejo, Pilar, y García Valverde, María (directoras), Derecho y medicina. Cuestiones jurídicas para profesionales de la salud (Cizur Menor, Thomson Reuters), pp. 450-477.

De la Maza Gazmurı, Íñigo (2010): “Consentimiento informado, una visión panorámica", en: Revista lus et Praxis (Año 16, № 2), pp. 89-120. 
Del Río SÁnchez, Carmen (2010): "El consentimiento informado en menores y adolescentes: Contexto ético-legal y algunas cuestiones problemáticas", en: Revista Información Psicológica (№ 100), pp. 60-67.

DíAz dE VALdés, José Manuel (2010): “Un marco constitucional para los tratamientos médicos de niños, niñas y adolescentes", en: Revista Chilena de Derecho ( $\left.\mathrm{N}^{\circ} 2\right)$, pp. 271-310.

Domínguez Hidalgo, Carmen (2016): "Autonomía en materia de niñez: Tensiones y perspectivas", en: Barría Paredes, Manuel (coordinador), Estudios de Derecho Civil XI (Santiago de Chile, Thomson Reuters), pp. 101-112.

(2014): "Responsabilidad civil y tratamiento de incapaces y discapacitados en la Ley No 20.584", en: Milos Hurtado, Paulina, y Corral Talciani, Hernán (editores), Derechos y deberes de los pacientes. Estudios y textos legales y reglamentarios (Santiago de Chile, Extensión Jurídica № 25), pp. 29-39.

Domínguez Luelmo, Andrés (2007): Derecho sanitario y responsabilidad médica. Comentarios a la Ley $N^{\circ} 41 / 2002$, de 14 de noviembre, sobre derechos del paciente, información y documentación clínica (Valladolid, Lex Nova).

EEKELAR, John (1998): "The emergence of children's rights", en: Oxford Journal of Legal Studies ( $\left.\mathrm{N}^{\circ} 2\right)$, pp. 161-187.

ESPEJO YAKSIC, Nicolás (2016): "El derecho a la vida familiar, los derechos del niño y la responsabilidad parental" en: Lepin Molina, Cristián, y Gómez de la Torre Vargas, Maricruz (coordinadores), Estudios de Derecho Familiar I (Santiago de Chile, Thomson Reuters), pp. 197-209.

Espejo YaKSIC, Nicolás, y Lathrop Gómez, Fabiola (2015): "Identidad de género, relaciones familiares y derechos de niños, niñas y adolescentes. Comentarios al proyecto de ley que reconoce y da protección al derecho a la identidad de género", en: Revista de Derecho Universidad Católica del Norte (№ 2), pp. 393-418.

FAMÁ, María Victoria (2017): "El derecho de niñas, niños y adolescentes a participar en las decisiones que los conciernen", en: Basset, Úrsula, y Fulchiron, Hugues (coordinadores), Tratado de la vulnerabilidad (Buenos Aires, Thomson Reuters), pp. 365-398.

Feldman, David (1993): Civil liberties and human rights in England and Wales (Oxford, Oxford University Press).

Fernández Costales, Javier (2007): "Estado actual de la casuística de la responsabilidad sanitaria, a la luz de los Consejos Consultivo del Consejo de Estado y de la jurisprudencia", en: Moreno Martínez, Juan Antonio (coordinador), La responsabilidad civil y su problemática actual (Madrid, Dykinson), pp. 255-280. 
Galán Cortés, Julio César (2016): Responsabilidad civil médica (Cizur Menor, Civitas).

García AlguaCiL, María José (2017): "Injerencia en el ámbito de los derechos de la personalidad del menor tras las leyes de 2015: ¿Autonomía o intervención?", en: Mayor del Hoyo, María Victoria (directora), El nuevo régimen jurídico del menor (Cizur Menor, Thomson Reuters), pp. 537-555.

(2012): "Alcance de la autonomía de la voluntad del menor maduro: El camino de la incoherencia legislativa", en: Boletín del Servicio de Estudios Registrales de Cataluña (№ 157), pp. 90-109.

García Andreu, Aznar (2000): "Sobre el respeto a la autonomía del paciente", en: Casado González, María (editora), Bioética y derecho (Valencia, Tirant lo Blanch), pp. 92-108.

García Garnica, María del Carmen (2010): Aspectos básicos de la responsabilidad civil médica (Cizur Menor, Aranzadi).

Gete-Alonso Calera, María del Carmen (2005): "Manifestaciones de la autonomía del menor en la normativa catalana", en: InDret ( $\mathrm{N}^{\circ} 1$ ), pp. 1-16.

(1998): "Protección del menor, consentimiento en el ámbito de las intervenciones sanitarias y libertad ideológica", en: La Notaría ( $N^{\circ}$ s. 11-12), pp. 48-53.

Gil Antón, Ana María (2015): ¿Privacidad del menor en internet? (Cizur Menor, Thomson Aranzadi).

Gitrama González, Manuel (1977): "En la convergencia de dos humanismos: Medicina y derecho", en: Anuario de Derecho Civil (No 1), pp. 273-335.

González Mirasol, Pablo (2005): "Autonomía sanitaria del menor y responsabilidad médica", en: La Ley (№ 4), pp. 1613-1635.

LAMA Aymá, Alejandra (2006): La protección de los derechos de la personalidad del menor de edad (Valencia: Tirant lo Blanch).

Le Tourneau, Philippe (2006): Droit de la responsabilité et des contrats (París, Dalloz).

LEÓN CoRREA, Francisco Javier (2012): "Información y consentimiento informado de menores de edad en Chile", en: Revista Chilena de Pediatría (Vol. 83, № 2), pp. 113-116.

López-Chapa, Sara (2007): Autonomía del paciente y libertad terapéutica (Barcelona, Bosch).

LóPEZ MeSA, Marcelo (2007): "Teoría general de la responsabilidad civil médica en el Derecho argentino y comparado", en: López Mesa, Marcelo (director), Tratado de responsabilidad médica: Responsabilidad civil, penal y hospitalaria (Buenos Aires, Legis), pp. 348-360. 
LORENTE LóPEZ, María Cristina (2015): Los derechos al honor, a la intimidad personal y familiar y a la propia imagen del menor (Cizur Menor, Thomson Aranzadi).

Lovera Parmo, Domingo A. (2017): "Ciudadanía constitucional de niños, niñas y adolescentes", en: Quesille, Anuar (coordinador), Constitución política e infancia. Una mirada desde los derechos de los niños, niñas y adolescentes en Chile (Santiago de Chile, Unicef), pp. 151-184.

(2009): "Libertad de expresión e interés superior del niño, a propósito de la sentencia de la Corte de Apelaciones de Antofagasta de 6 de marzo de 2009 y Corte Suprema de 23 de abril de 2009", en: Revista Chilena de Derecho Privado (No 12), pp. 215-225.

Llamas Pombo, Eugenio (1988): La responsabilidad civil del médico: Aspectos tradicionales y modernos (Madrid, Trívium).

Martínez-Pereda Rodríguez, José Manuel (2006): "Algunos efectos producidos por la implantación del consentimiento informado en España", en: La Ley ( No 6.524), pp. 1-27.

Ministerio de SAlud (2017): "Memorándum A15 № 03681". Disponible en: https://diprece.minsal.cl/wrdprss_minsal/wp-content/uploads/2017/12/ Sobre-informacion-sensible-y-consentimiento-NNA-SENAME.pdf [visitado el 28.09.2019].

(2016): "Circular No A15". Disponible en: https://diprece.minsal. cl/wrdprss_minsal/wp-content/uploads/2017/12/Circular-Materia-deAnticoncepci\%C3\%B3n-2016.pdf [visitado el 28.09.2019].

Moreno Bobadilla, Ángela (2017): Intimidad y menores (Madrid, Centro de Estudios Políticos y Constitucionales).

Ogando Díaz, Beatriz, y García Pérez, César (2007): "Consentimiento informado y capacidad para decidir del menor maduro", en: Pediatría Integral (Vol. 11, $\left.\mathrm{N}^{\mathrm{o}} 10\right)$, pp. 877-883.

OtÁROlA ESPINOZA, Yasna (2017): "El derecho de los niños y adolescentes a expresarse a través de las movilizaciones estudiantiles como parte del principio del libre desarrollo de la personalidad", en: Acuña San Martín, Marcela, y Del Picó Rubio, Jorge (editores), Estudios de Derecho Familiar. Segundas Jornadas Nacionales de Derecho de Familia (Talca, Editorial de Talca), pp. 253-267. Parra Sepúlveda, Darío (2018): "El consentimiento informado de niños, niñas y adolescentes en el ámbito sanitario", en: Domínguez Hidalgo, Carmen (coordinadora), Estudios de Derecho de Familia III (Santiago de Chile, Thomson Reuters), pp. 331-349. 
(2014): "La evolución ético-jurídica de la responsabilidad médica", en: Acta Bioethica (Vol. 20, № 2), pp. 207-213.

Parra SepúlvedA, Darío (2013): "La obligación de informar al paciente. Cuestiones sobre el derecho a ser informado", en: Revista Médica de Chile (Vol. 141, No 12), pp. 1578-1583.

Pérez Venegas, Francisco (1997): "El secreto médico profesional y situaciones de conflicto", en: Revista General del Derecho (Nºs. 628-629), pp. 147-158.

Pinto Bustamante, Julián, y Gulfo Díaz, Raisa (2013): “Asentimiento y consentimiento informado en pediatría: Aspectos bioéticos y jurídicos en el contexto colombiano", en: Revista Colombiana de Bioética (Vol. 8, № 1), pp. 144-165.

Ravetllat Ballesté, Isaac, y Sanabria Moudelle, Claudia (2016): "El ejercicio del derecho a la salud sexual y reproductiva por parte de las personas adolescentes en el contexto paraguayo. El respeto a su interés superior", en: Revista Pediatría, Asunción (Vol. 43, № 1), pp. 59-76.

RAVETLLAt Ballesté, Isaac (2017): "El consentimiento informado de la persona menor de edad a los tratamientos e intervenciones médicas", en: La Ley Derecho de Familia: Revista Jurídica sobre Derecho y Menores ( $N^{\circ} 13$ ), pp. 30-44.

(2018): "Igual de diferentes: La identidad de género de niñas, niños y adolescentes en Chile", en: Revista lus et Praxis (Año 24, № 1), pp. 397-436.

(2016a): "La toma de decisiones de los progenitores en el ámbito sanitario: A vueltas con el interés superior del niño a propósito de la sentencia de la Corte Suprema de 3 de marzo de 2016", en: Revista lus et Praxis (Año 22, No 2), pp. 499-512.

(2016b): "Responsabilidad negocial de los actos realizados por personas impúberes: Especial referencia a los actos relativos a bienes o servicios propios de su edad, de acuerdo con los usos sociales", en: Barría Paredes, Manuel (coordinador), Estudios de Derecho Civil XI (Santiago de Chile, Thomson Reuters), pp. 213-224.

(2015): "Trascendencia actual de la clásica cuestión del dolo aliquid minor en el Derecho civil patrimonial chileno", en Vidal Olivares, Álvaro; Severin Fuster, Gonzalo, y Mejías Alonzo, Claudia (editores), Estudios de Derecho Civil X (Santiago de Chile, Thomson Reuters), pp. 739-750.

(2013): El ejercicio de los derechos a la vida y a la integridad física por parte de las personas menores de edad en el ámbito sanitario (Barcelona, Huygens).

Rivero Herández, Francisco (2007): El interés del menor (Madrid, Dykinson). 
Rueda Castro, Laura (2008): "Consentimiento informado en niños y adolescentes", en: Ars Médica. Revista de Ciencias Médicas (Vol. 31, № 1), pp. 1-15.

Ruíz JIMÉNEZ, Juana (2009): "La capacidad del menor en el ámbito sanitario", en: Pous de la Flor, María Paz (editora), La capacidad de obrar del menor: Nuevas perspectivas jurídicas (Madrid, Exlibris), pp. 75-92.

Sabatello, Maya (2009): Children's bioethics: The international biopolitical discourse on harmful traditional practices and the right of the child to cultural identity (Leiden, Koninklijke Brill).

SÁnchez González, María Paz (2002): La impropiamente Ilamada objeción de conciencia a los tratamientos médicos (Valencia, Tirant lo Blanch).

SÁnchez HeRnández, Carmen (2003): "Capacidad natural e interés del menor maduro como fundamentos del libre ejercicio de los derechos de la personalidad", en: Cabanillas Sánchez, Antonio (coordinador), Estudios jurídicos en homenaje al Prof. Luis Díez-Picazo. Tomo I. Semblanzas. Derecho civil. Parte general (Madrid, Thomson Civitas), pp. 951-974.

SANTOS Briz, Jaime (2001): La responsabilidad civil. Temas actuales (Madrid, Montecorvo).

Santos Morón, María José (2011): "Menores y derechos de la personalidad. La autonomía del menor", en: Díaz-Maroto y Villarejo, Julio, y Rodríguez Guitán, Alma (coordinadores), El menor ante el derecho en el siglo XXI (Madrid, Anuario de la Facultad de Derecho de la Universidad Autónoma de Madrid), pp. 63-93.

VARAs Braun, Juan Andrés (2010): “Decisiones vitales y representación parental: fundamento y límites", en: Departamento de Derecho Privado de la Universidad de Concepción (coordinación), Estudios de Derecho Civil V, Jornadas Nacionales de Derecho Civil, Concepción (Santiago de Chile, LegalPublishing), pp. 337-356.

Verdera IZQUIERDO, Beatriz (2017): “El interés del menor versus interés familiar e interés particular de los progenitores", en: Mayor del Hoyo, María Victoria (directora), El nuevo régimen jurídico del menor (Cizur Menor, Thomson Reuters), pp. 519-535.

\section{NORMAS JURÍDICAS CITADAS}

Código Civil, Chile.

Ley $\mathrm{N}^{\circ} 20.584$, regula los derechos y deberes que tienen las personas en relación con acciones vinculadas a su atención en salud. Diario Oficial, 24.04.2012. 
Ley № 20.418, fija normas sobre información, orientación y prestaciones en materia de regulación de la fertilidad. Diario Oficial, 28.01.2010.

Ley No 19.968, crea los Tribunales de Familia. Diario Oficial, 30.08.2004.

Decreto del Ministerio de Salud $N^{\circ} 31$, aprueba el reglamento sobre entrega de información y expresión de consentimiento informado en las atenciones de salud. Diario Oficial, 26.11.2012.

Circular N ${ }^{\circ}$ A15/10 del Ministerio de Salud, sobre atención de adolescentes en materia de salud, 7.10.2016.

Convenio del Consejo de Europa, sobre derechos humanos y biomedicina, 4.04.1997.

Children's Act, Reino Unido, 16.11.1989.

\section{JURISPRUDENCIA CITADA}

Sentencia dictada por el Tribunal Supremo español de 13 de mayo de 2011, en causa RJ 2011, 3279. 
